\title{
PENGARUH PRAKTIK KERJA INDUSTRI (PRAKERIN) DAN PRESTASI BELAJAR MATA PELAJARAN PRODUKTIF TERHADAP KESIAPAN KERJA SISWA KELAS XII TEKNIK GAMBAR BANGUNAN SMK NEGERI 1 MADIUN TAHUN 2017/2018
}

\author{
Novie Annisya Nusantika Putri ${ }^{1}$, A.G. Thamrin ${ }^{2}$, Rima Sri Agustin ${ }^{2}$ \\ Email: novieannisya@yahoo.com
}

\begin{abstract}
ABSTRAK
Penelitian ini bertujuan untuk mengetahui : (1) Pengaruh Praktik Kerja Industri (PRAKERIN) terhadap kesiapan kerja siswa kelas XII Teknik Gambar Bangunan SMK Negeri 1 Madiun. (2) Pengaruh prestasi mata pelajaran produktif terhadap kesiapan kerja siswa kelas XII Teknik Gambar Bangunan SMK Negeri 1 Madiun. (3) Pengaruh keduanya terhadap kesiapan kerja siswa kelas XII Teknik Gambar Bangunan SMK Negeri 1 Madiun. Penelitian ini menggunakan metode penelitian kuantitatif deskriptif. Populasi adalah siswa kelas XII Teknik Gambar Bangunan di SMK Negeri 1 Madiun tahun ajaran 2017/2018 sebanyak 41 siswa. Teknik pengambilan sampel yang digunakan dalam penelitian ini adalah total sampling. Metode pengumpulan data menggunakan wawancara, dokumentasi, kuisioner/angket. Pengolahan data menggunakan teknik analisis regresi linear berganda dengan uji prasyarat analisis yaitu, uji normalitas residual, uji linieritas, uji multikolinearitas. Hasil penelitian ini adalah sebagai berikut: (1) Berdasarkan hasil uji t antara variabel Praktik Kerja Industri (PRAKERIN) $\left(\mathrm{X}_{1}\right)$ dan variabel kesiapan kerja (Y) diperoleh nilai sign 0,000 ini menunjukkan bahwa nilai sign pada hasil SPSS $<0,05$, maka Ho ditolak dan $\mathrm{Ha}$ diterima sehinga terdapat pengaruh antara Praktik Kerja Industri (PRAKERIN) $\left(\mathrm{X}_{1}\right)$ terhadap kesiapan kerja (Y). (2) Berdasarkan hasil uji t antara variabel prestasi belajar mata pelajaran produktif $\left(\mathrm{X}_{2}\right)$ dan variabel kesiapan kerja $(\mathrm{Y})$ diperoleh nilai sign 0,065 ini menunjukkan bahwa nilai sign pada hasil SPSS > 0,05, maka Ho diterima dan $\mathrm{Ha}$ ditolak sehinga tidak terdapat pengaruh antara prestasi belajar mata pelajaran produktif $\left(\mathrm{X}_{2}\right)$ terhadap kesiapan kerja (Y). (3) Berdasarkan hasil uji F diperoleh nilai sign 0,000 ini menunjukkan bahwa nilai sign pada hasil SPSS $<0,05$, maka Ho ditolak dan Ha diterima sehinga terdapat pengaruh Praktik Kerja Industri (PRAKERIN) $\left(\mathrm{X}_{1}\right)$ dan prestasi belajar mata pelajaran produktif $\left(\mathrm{X}_{2}\right)$ terhadap kesiapan kerja $(\mathrm{Y})$.
\end{abstract}

Kata Kunci: Praktik Kerja Industri (PRAKERIN), Prestasi Belajar, Kesiapan Kerja

\footnotetext{
${ }^{1}$ Mahasiswa Program Studi Pendidikan Teknik Bangunan FKIP UNS

${ }^{2}$ Dosen Pengajar Program Studi Pendidikan Teknik Bangunan FKIP UNS
} 


\title{
THE INFLUENCE OF INDUSTRIAL WORK PRACTICE AND LEARNING ACHIEVEMENT IN PRACTICE-ORIENTED COURSES TOWARD WORK READINESS OF YEAR 2017/2018 OF XII STUDENTS MAJORING BUILDING DESIGN AND BUILDING INFORMATION MODELLING IN SMK NEGERI 1 MADIUN.
}

\author{
Novie Annisya Nusantika Putri ${ }^{1}$, A.G. Thamrin ${ }^{2}$, Rima Sri Agustin ${ }^{2}$ \\ Email: novieannisya@yahoo.com
}

\begin{abstract}
This research aimed at identifying (1) the influence of industrial work practice on the work readiness of XII students majoring Building Design and Building Information Modelling in SMK Negeri 1 Madiun, (2) the influence of learning achievement in practiceoriented courses toward work readiness of XII students majoring Building Design and Building Information Modelling in SMK Negeri 1 Madiun, (3) the influence between Industrial Work Practice and learning achievement of practice-oriented courses toward work readiness of XII students majoring Building Design and Building Information Modelling in SMK Negeri 1 Madiun. The research employed descriptive quantitative method. The population was 41 students of XII class majoring Building Design and Building Information Modelling year of 2017/2018 in SMK Negeri 1 Madiun. The Sampling technique used was research total sampling. The data were gathered through interviews, documents, and questionnaires. The data were analyzed by using multiple linear regression analysis technique with analysis prerequisites testing, i.e. residual normality testing, linearity testing, multicollinearity testing. The research results indicated that: (1) Based on t test result between Industrial Work Practice variable $\left(X_{1}\right)$ and work readiness variable $(Y)$, it was found that the sign scoring 0.000 showed that the sign value of SPSS result $<0.05$. Therefore, Ho was rejected and Ha was accepted and it suggested that there was an influence of Industrial Work Practice) $\left(X_{1}\right)$ toward work readiness $(Y)$. (2) Based on t test result between learning achievement of practice-oriented courses $\left(X_{2}\right)$ and work readiness $(Y)$, it was found that the sign scoring 0.065 showed that the sign value of SPSS result $>0.05$. Therefore, Ho was accepted and Ha was rejected and it suggested that there was no influence of practice-oriented courses $\left(X_{2}\right)$ toward work readiness $(Y)$. (3) Based on F test result, it was found the sign scoring 0.000 showed that the sign value of SPSS result $<0.05$. Therefore, Ho was rejected and Ha was accepted and it suggested that there was a significant influence between Industrial Work Practice $\left(X_{1}\right)$ and learning achievement of practice-oriented courses $\left(X_{2}\right)$ toward work readiness $(Y)$.
\end{abstract}

Keywords: Industrial Work Practice, Learning Achievement, Work Readiness

\footnotetext{
${ }^{1}$ Student of Building Engineering of Education FKIP UNS

${ }^{2}$ Lecturer of Building Engineering of Education FKIP UNS
} 


\section{PENDAHULUAN}

Sekolah Menengah Kejuruan ialah jalur pendidikan formal yang telah diselenggarakan guna mempersiapkan bakal calon tenaga kerja kelas menengah dalam memasuki dunia usaha, baik untuk menjawab tantangan kebutuhan tenaga kerja dan menciptakan lapangan kerja atau wirausaha. SMK mempunyai karakteristik yang berbeda dengan SMU, dikarenakan pada SMK lebih menekankan pada usaha mempersiapkan peserta didik guna mendapatkan suatu pekerjaan pada bidang tertentu. Dengan adanya dorongan yang seperti itu maka peserta didik tidak bisa hanya mendapatkan pelajaran dari sekolah, tetapi juga diwajibkan untuk melaksanakan Praktik Kerja Industri yang nantinya juga berguna sebagai bekal mereka untuk menghadapi dunia kerja.

Tujuan dari Praktik Kerja Industri sendiri guna mengetahui kesiapan peserta didik dalam menghadapi dunia kerja.

Praktik Kerja Industri adalah "kegiatan wajib bagi siswa Sekolah Menengah Kejuruan (SMK) yaitu kegiatan belajar dengan objek dan tempat langsung di Dunia Usaha / Dunia Industri. Proses pembelajaran di dunia kerja (DU/DI) disebut dengan Praktik Kerja Industri (PRAKERIN) untuk penerapan, pemantapan, dan peningkatan kompetensi. Dalam pelaksanaan melibatkan praktisi ahli yang berpengalaman di bidang melalui bimbingan praktik" (Dikmenjur, 2017).

Menurut Hamalik (2007) dalam Syailla (2017:472) yaitu Praktik
Kerja Industri ialah suatu rancangan pelatihan yang dilakukan di lapangan bertujuan untuk memberikan kecakapan yang diperlukan dalam pekerjaan tertentu sesuai dengan tuntutan kemampuan bagi pekerjaan tersebut Praktik Kerja Industri bukan hanya pelatihan langsung dilapangan, namun juga memberikan pengalaman bekerja langsung.

Menurut Anis (2016:13) manfaat Praktik Kerja Industri sebagai berikut

a) Mendapatkan pengalaman dan wawasan baru

b) Mampu melatih siswa untuk lebih terampil

c) Membantu pola pikir siswa agar dapat bersikap dewasa di dalam memecahkan suatu masalah

d) Membantuk siswa memiliki ke siapan untuk memasuki dunia kerja

e) Dapat meningkatkan kualitas keterampilan

f) Membentuk sikap, loyalitas, dan kerjasama

Menurut Hamalik (2007:120126) evaluasi atau penilaian hasilnya pelatihan atau Praktik Kerja Industri meliputi beberapa hal yaitu :

a) Evaluasi aspek pengetahuan
a. Kemauan kerja
b. Kemampuan memahami manajemen proyek
c. Kemampuan memahami pekerjaan proyek

b) Evaluasi aspek keterampilan
a. Keterampilan kerja
b. Keterampilan menjaga kualitas kerja
c. Keterampilan menyelesaikan pekerjaan
d. Beradaptasi 
c) Evaluasi aspek sikap
a. Bertanggung Jawab
b. Disiplin
c. Profesional
d. Percaya diri

Menurut Anis (2016:70) dalam Hettich (O'Brien, et al, 2013:2) bahwa kecerdasan berkontribusi terhadap kesiapan kerja. Prestasi belajar merupakan hasil yang telah dicapai siswa yang menunjukkan kemajuan siswa yang berkenaan dengan penguasaan bahan pelajaran dan pengetahuan. Siswa yang memiliki nilai yang tinggi menunjukkan bahwa keberhasilan siswa menguasai bahan pelajaran dan pengetahuan tinggi. Sehingga semakin tinggi penguasaan bahan pelajaran yang menyangkut pengetahuan dan keterampilan siswa maka semakin tinggi pula kesiapan kerjanya.

Menurut Suryati (2017:12) dalam Arifin (1990:3), fungsi pretasi belajar yaitu:

a) Sebagai indikator kualitas dan kuantitas pengetahuan yang sudah dikuasai anak didik ,sebagai indikator internal dan eksternal dari suatu institusi pendidikan, serta sebagai daya serap (kecerdasan anak didik).

b) Sebagai lambang pemuasan hasrat ingin tahu.

c) Sebagai bahan informasi dalam inovasi pendidikan.

Menurut Hamdani (2011:139) menyatakan bahwa faktor-faktor yang mempengaruhi prestasi belajar adalah faktor internal (kecerdasan, faktor fisiologis, sikap, minat, bakat, dan motivasi) dan faktorpeksternal (keadaan keluarga, keadaan sekolah, dan lingkungan masyarakat).
Sukardi (2008) "Kesiapan kerja meliputi berbagai kemampuan, keterampilan, dan sikap yang sesuai dengan tuntutan masyarakat, serta sesuai dengan potensi siswa dalam berbagai jenis pekerjaan tertentu yang secara langsung dapat diterapkan". Sehingga peserta didik dengan lulusan yang memiliki kemampuan, keterampilan, sikap, dan potensi tentunya akan mudah memasuki dunia kerja, bersaing, dan berkembang (Novita Sri Arum Sari, 2016).

Sedangkan menurut Pool dan Sewell (2007) dalam Candra Sari Hawa (2016) menyatakan kesiapan kerja terdiri dari empat aspek yaitu :

a) Keterampilan, kemampuanyang dibutuhkan untuk melaksanakan beberapa tugas yang berkembang dari hasil pelatihan dan pengalaman yang didapat. Dari aspek keterampilan ini terdapat beberapa indikator, seperti :
a. Kreatif dan inovatif
b. Bekerja sama
c. Memecahkan masalah
d. berkomunikasi

b) Ilmu pengetahuan, yang menjadikan pendidikan sebagai dasarsecara teoritis sehingga memiliki kemampuan untuk menjadi ahli sesuai dengan bidangnya. Sebagai fcalon lulusan SMK harus memiliki wawasan dan pengetahuan yang luas.

c) Pemahaman, kemampuan seseorang untuk mengerti atau memahami sesuatu yang telah diketahui dan diingat, sehingga pekerjaannnya bisa dilakukan dan diperoleh kepuasan sekaligus mengetahui apa yang 
menjadi keinginannya. Dari aspek Pemahaman ini terdapat beberapa indikator, seperti :
a. Kemampuan memahami gambar dan pengoperasian computer
b. Kemampuan mempersiapkan diri
c. Kemampuan mengambil keputusan

d) Atribut kepribadian, mendorong seseorang dalam memunculkan potensi yang ada dalam diri. Dari aspek atribut kepribadian ini terdapat beberapa indikator, seperti :
a. Etika kerja
b. Tanggung jawab
c. Optimis
d. Ketekunan
e. Kepercayaan diri
Dalam peraturan pemerintah Republik Indonesia tahun 2003 tentang pendidikan kejuruan, vokasi dan profesi "Pendidikan kejuruan adalah pendidikan menengah yang mempersiapkan peserta didik terutama untuk bekerja dalam bidang tertentu.".

Fungsi dari pendidikan kejuruan menurut peraturan pemerintah Republik Indonesia Tahun 2003, ialah :
a) Menyiapkan peserta didik menjadi menusia produktif yang siap bekerja
b) Mampu bekerja mandiri dan mengisi lowongan pekerjaan yang ada di DU/DI sebagai tenaga kerja kelas menengah
c) Memiliki sikap ulet dan gigih dalam berkompetensi, beradaptasi dengan lingkungan dan mengembangkan sikap profesional.

d) Mampu mengembangkan diri secara bekelanjutan.

Berdasarkan dari berbagai pendapat diatas mengenai Praktik Kerja Industri, Prestasi Belajar, Kesiapan Kerja dan Sekolah Menengah Kejuruan, penelitian ini bertujuan untuk mengetahui pengaruh tentang Praktik Kerja Industri terhadap kerja, pengaruh prestasi belajar terhadap kesiapan kerja, serta pengaruh Praktik Kerja Industri dan prestasi belajar terhadap kesiapan kerja.

\section{METODE PENELITIAN}

Penelitian dilaksanakan di SMK Negeri 1 Madiun yang beralamat Jalan MH. Thamrin 1, Oro Oro Ombo, Kartoharjo, Oro-oro Ombo, Kartoharjo, Kota Madiun, Jawa Timur 63119. Waktu penelitian Juli 2018 - Desember 2018.

Penelitian ini menggunakan metode penelitian kuantitatif deskriptif. Data dalam penelitian dari angket/kuisioner dan wawancara mengenai Praktik Kerja Industri (PRAKERIN) dan Kesiapan Kerja, dan dokumentasi berupa rapor siswa khusus mata pelajaran produktif.

Populasi adalah siswa kelas XII Teknik Gambar Bangunan di SMK Negeri 1 Madiun tahun ajaran 2017/2018 sebanyak 41 siswa.

Teknik pengambilan sampel yang digunakan dalam penelitian ini adalah total sampling. Metode pengumpulan data menggunakan wawancara, dokumentasi, kuisioner/angket. Uji instrumen menggunakan uji validitas dan uji reliabilitas serta untuk pengolahan data menggunakan teknik analisis regresi linear berganda dengan uji prasyarat analisis yaitu, uji normalitas residual, uji linieritas, uji 
multikolinearitas. Sedangkan pengujian hipotesis menggunakan uji $t$ dan uji $F$, kedua uji ini akan dicari nilai sign. guna mengetahui hipotesis awal diterima atau ditolak. Pengujian menggunakan program SPSS versi 24.0.

\section{HASIL DAN PEMBAHASAN Deskripsi Data}

Deskripsi data merupakan hasil uji validitas dan uji reliabilitas dari angket/kuisioner tentang Praktik Kerja Industri dan Kesiapan Kerja yang telah disebarkan kepada siswa kelas XII TGB SMK Negeri 1 Madiun.

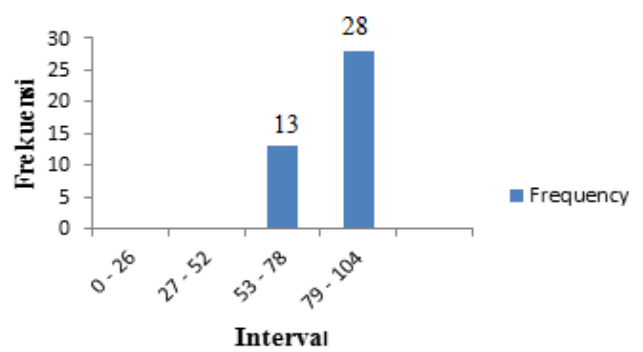

Gambar1. Histogram Data Praktik Kerja Industri

Tabel 1. Kategori Penilaian

\begin{tabular}{|c|l|}
\hline $79-104$ & Sangat Setuju \\
\hline $53-78$ & Setuju \\
\hline $27-52$ & Kurang Setuju \\
\hline $0-26$ & Tidak Setuju \\
\hline
\end{tabular}

Berdasarkan gambar 1 Hasil instrumen angket Praktik Kerja Industri dimana jumlah skor ideal untuk seluruh item yaitu nilai tertinggi pada instrumen $\mathrm{x}$ jumlah siswa, jadi 4 x $41=164$ ( jika semua siswa menjawab sangat setuju). Berdasarkan data tersebut maka tingkat persetujuan terhadap Praktik Kerja Industri yaitu (151 : 164) $\mathrm{x}$ $100 \%=92 \%$ dari yang diharapkan (75\%), jadi kesimpulannya mayoritas siswa setuju dengan adanya Praktik Kerja Industri (PRAKERIN).

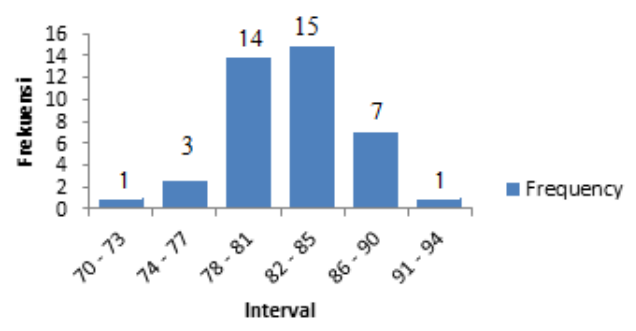

Gambar2. Histogram Prestasi Belajar Tabel 2. Kategori Penilaian

\begin{tabular}{|c|l|}
\hline $86 \% / \mathrm{d} 100$ & Sangat Baik \\
\hline $70 \mathrm{~s} / \mathrm{d} 85$ & Baik \\
\hline $60 \% \mathrm{~d} 69$ & Cukup \\
\hline $0 \% \mathrm{~d} 59$ & Kurang \\
\hline
\end{tabular}

Berdasarkan gambar 2 Hasilhasil perhitungan data jumlah nilai ideal untuk seluruh item yaitu nilai tertinggi prestasi belajar mata pelajaran produktif $\mathrm{x}$ jumlah siswa, jadi 100 x $41=4100$ ( jika semua siswa mendapatkan nilai 100). Berdasarkan data tersebut maka tingkat pencapaian prestasi belajar mata pelajaran produktif yaitu (3605 : 4100) $\mathrm{x} 100 \%=87,93 \%$ dari yang diharapkan (70\%), jadi kesimpulannya mayoritas siswa sudah baik dalam pencapaian prestasi belajar mata pelajaran produktif

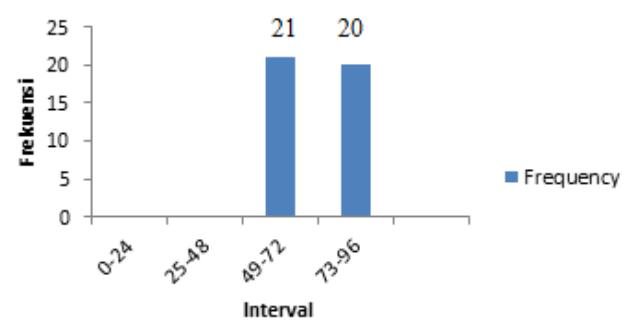

Gambar3. Histogram Kesiapan Kerja Tabel 3. Kategori Penilaian

\begin{tabular}{|c|l|}
\hline $73-96$ & Sangat Setuju \\
\hline $49-72$ & Setuju \\
\hline $25-48$ & Ragu - Ragu \\
\hline $0-24$ & Tidak Setuju \\
\hline
\end{tabular}

Berdasarkan gambar 3 Hasil instrumen angket kesiapan kerja dimana jumlah skor ideal untuk 
seluruh item yaitu nilai tertinggi pada instrumen $\mathrm{x}$ jumlah siswa, jadi 4 x 41 $=164$ (jika semua siswa menjawab sangat setuju). Berdasarkan data tersebut maka tingkat persetujuan terhadap kesiapan kerja yaitu (143 : 164) $\mathrm{x} 100 \%=87,2 \%$ dari yang diharapkan (75\%), jadi kesimpulannya mayoritas siswa sudah siap dalam mempersiapkan diri terjun ke dunia kerja.

\section{Hasil Uji Prasyarat Analisis}

a. Uji Normalitas Residual

Tabel 4. Hasil Uji Normalitas

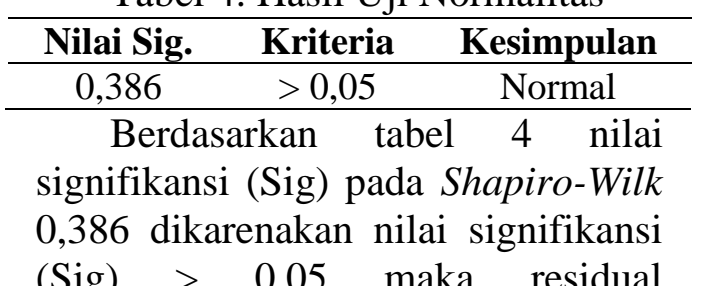
terdistribusi dengan normal.

b. Uji Linieritas

Tabel 5. Hasil Uji $X_{1}$ dan Y

\begin{tabular}{cccc}
\hline Variabel & Nilai Sig. & Kriteria & Kesimpulan \\
\hline $\mathrm{X} 1$ dan $\mathrm{Y}$ & 0,273 & $>0,05$ & Limienitas \\
\hline
\end{tabular}

Berdasarkan tabel 5 nilai sign. dilihat dari output perhitungan Deviation from Linearity sebesar 0,273 , ini menunjukkan bahwa nilai Sig. > 0,05 maka dapat disimpulkan bahwa variabel bebas Praktik Kerja Industri dan variabel terikat kesiapan kerja terdapat hubungan yang linear. Tabel 6. Hasil Uji $\mathrm{X}_{2}$ dan $\mathrm{Y}$

\begin{tabular}{cccc}
\hline Variabel & Nilai Sig, & Kriteria & Kesimpulan \\
\hline $\mathrm{X} 2$ dan $\mathrm{Y}$ & 0,461 & $>0,05$ & Limientas \\
\hline Berdasarkan & tabel & 6 & nilai
\end{tabular}
signifikansi dilihat dari output perhitungan Deviation from Linearity (Lampiran 21) sebesar 0,461, ini menunjukkan bahwa nilai Sig. > 0,05 maka dapat disimpulkan bahwa variabel bebas prestasi belajar mata pelajaran produktif dan variabel terikat kesiapan kerja terdapat hubungan yang linear.

c. Uji Multikolinearitas

Tabel 7. Hasil Uji Multikolinearitas

\begin{tabular}{|c|c|c|c|c|}
\hline $\begin{array}{l}\text { Vari } \\
\text { abel }\end{array}$ & $\begin{array}{l}\text { Toler } \\
\text { ance }\end{array}$ & Kesimpulan & VIF & Kesimpulan \\
\hline $\mathrm{X} 1$ & 0,793 & Tidak terjadi & 1,260 & Tidak terjadi \\
\hline $\mathrm{X} 2$ & 0,793 & multikolinearitas & 1,260 & multikolinearitas \\
\hline
\end{tabular}
tolerance pada variabel Praktik Kerja Industri sebesar 0,793>0,10 dan nilai tolerance pada variabel Prestasi belajar mata pelajaran produktif sebesar 0,793 > 0,10 maka keduanya tidak terjadi multikolinearitas. Sedangkan nilai VIF pada variabel Praktik Kerja Industri sebesar 1,260 < 10 dan nilai VIF pada variabel Prestasi belajar mata pelajaran produktif sebesar $1,260<10$ maka keduanya tidak terjadi multikolinearitas. Sehingga dapat disimpulkan bahwa Tolerance dan VIF tidak terjadi Multikolinearitas.

\section{Hasil Uji Hipotesis}

a. Uji t

Tabel 8. Hasil Uji t

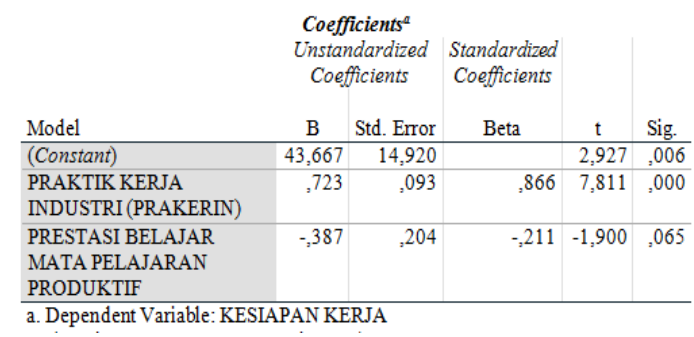

Berdasarkan tabel 8 hasil uji t, dapat dijelaskan sebagai berikut :

Hipotesis pertama pada penelitian ini menyebutkan bahwa ada pengaruh Praktik Kerja Industri terhadap kesiapan kerja. Berdasarkan hasil uji $\mathrm{t}$ antara variabel Praktik Kerja Industri $\left(\mathrm{X}_{1}\right)$ dan variabel kesiapan kerja (Y) diperoleh nilai sign 0,000 ini menunjukkan bahwa nilai sign pada hasil SPSS $<0,05$, maka Ho ditolak dan $\mathrm{Ha}$ diterima 
sehinga terdapat pengaruh antara Praktik Kerja Industri $\left(\mathrm{X}_{1}\right)$ terhadap kesiapan kerja (Y).

Hipotesis kedua pada penelitian ini menyebutkan bahwa ada pengaruh prestasi belajar mata pelajaran produktif terhadap kesiapan kerja. Berdasarkan hasil uji $t$ antara variabel prestasi belajar mata pelajaran produktif $\left(\mathrm{X}_{2}\right)$ dan variabel kesiapan kerja (Y) diperoleh nilai sign 0,065 ini menunjukkan bahwa nilai sign pada hasil SPSS > 0,05, maka Ho diterima dan Ha ditolak sehinga tidak terdapat pengaruh antara prestasi belajar mata pelajaran produktif $\left(\mathrm{X}_{2}\right)$ terhadap kesiapan kerja (Y).

b. $\mathbf{U j i} \mathbf{F}$

Tabel 9. Hasil Uji t

\begin{tabular}{|c|c|c|c|c|c|}
\hline \multicolumn{6}{|c|}{ ANOVA $^{\mathrm{a}}$} \\
\hline Model & $\begin{array}{l}\text { Sum of } \\
\text { Squares }\end{array}$ & df & Mean Square & $\mathrm{F}$ & Sig. \\
\hline 1 Regression & 1507,534 & 2 & 753,767 & 32,225 &, $000^{b}$ \\
\hline Residual & 888,856 & 38 & 23,391 & & \\
\hline Total & 2396,390 & 40 & & & \\
\hline
\end{tabular}

a. Dependent Variable: KESIAPAN KERJA

b. Predictors: (Constant), PRESTASI BELAJAR MATA PELAJARAN PRODUKTIF, PRAKTIK KERJA INDUSTRI (PRAKERIN)

Hipotesis ketiga pada penelitian ini menyebutkan bahwa ada pengaruh Praktik Kerja Industri dan prestasi belajar mata pelajaran produktif terhadap kesiapan kerja. Berdasarkan hasil uji $\mathrm{F}$ diperoleh nilai sign 0,000 ini menunjukkan bahwa nilai sign pada hasil SPSS $<0,05$, maka Ho ditolak dan Ha diterima sehinga terdapat pengaruh Praktik Kerja Industri $\left(\mathrm{X}_{1}\right)$ dan prestasi belajar mata pelajaran produktif $\left(\mathrm{X}_{2}\right)$ terhadap kesiapan kerja (Y).

\section{c. Uji Pengaruh}

Tabel 10. Hasil Perhitungan SE dan SR

\begin{tabular}{ccc}
\hline \multirow{2}{*}{ Variabel } & \multicolumn{2}{c}{ Sumbangan } \\
\cline { 2 - 3 } & Relatif (\%) & Efektif $(\%)$ \\
\hline $\mathrm{X} 1$ & $106,13 \%$ & $66,76 \%$ \\
\hline $\mathrm{X} 2$ & $-6,13 \%$ & $-3,86 \%$ \\
\hline Total & $100 \%$ & $62,9 \%$ \\
\hline
\end{tabular}

Berdasarkan tabel 10 hasil perhitungan tersebut dapat diketahui bahwa SR antara variabel Praktik Kerja Industri $\left(\mathrm{X}_{1}\right)$ terhadap variabel kesiapan kerja (Y) sebesar 106,13\% dan SR antara variabel prestasi belajar mata pelajaran produktif $\left(\mathrm{X}_{2}\right)$ terhadap variabel kesiapan kerja (Y) sebesar $-6,13 \%$, dengan total SR sebesar $100 \%$. SE antara variabel Praktik Kerja Industri $\left(\mathrm{X}_{1}\right)$ terhadap variabel kesiapan kerja (Y) sebesar $66,76 \%$ dan SE antara variabel prestasi belajar mata pelajaran produktif $\left(\mathrm{X}_{2}\right)$ terhadap variabel kesiapan kerja (Y) sebesar -3,86 \%, dengan total SE sebesar 62,9 \% yang artinya sama dengan koefisien determinan $R$ square analisis regresi sebesar $62,9 \%$.

\section{Pengaruh Praktik Kerja Industri (PRAKERIN) terhadap kesiapan kerja} Berdasarkan data hasil uji hipotesis dengan menggunakan analisis regresi linear berganda, Berdasarkan hasil uji $\mathrm{t}$ antara variabel Praktik Kerja Industri (PRAKERIN) dan variabel kesiapan kerja diperoleh nilai sign 0,000 ini menunjukkan bahwa nilai sign pada hasil SPSS $<0,05$, maka Ho ditolak dan Ha diterima 
sehingga terdapat pengaruh antara Praktik Kerja Industri (PRAKERIN)

terhadap kesiapan kerja. Hal ini diperkuat dengan pendapat Hamalik (2007) dalam Syailla (2017 : 472) yaitu praktik industri merupakan model pelatihan yang diselenggarakan di lapangan, bertujuan untuk memberikan kecakapan yang diperlukan dalam pekerjaan tertentu sesuai dengan tuntutan kemampuan bagi pekerjaan. Praktik Kerja Industri bukan hanya pelatihan langsung dilapangan, namun juga memberikan pengalaman bekerja langsung. Dari pendapat hamalik tersebut bisa dikatakan jika siswa khususnya Sekolah Menengah Kejuruan (SMK) wajib diselenggarakan Praktik Kerja Industri karena ini merupakan modal awal siswa dalam belajar bagaimana menghadapi dunia kerja yang sesungguhnya.

2. Pengaruh prestasi belajar mata pelajaran produktif terhadap kesiapan kerja

Berdasarkan data hasil uji hipotesis dengan menggunakan analisis regresi linear berganda, hasil Berdasarkan hasil uji t antara variabel prestasi belajar mata pelajaran produktif dan variabel kesiapan kerja diperoleh nilai sign 0,065 ini menunjukkan bahwa nilai sign pada hasil SPSS $>0,05$, maka Ho diterima dan Ha ditolak sehinga tidak terdapat pengaruh antara prestasi belajar mata pelajaran produktif terhadap kesiapan kerja. Hal tersebut menunjukkan bahwa nilai prestasi belajar mata pelajaran produktif (Gambar Teknik, Gambar Konstruksi Bangunan, Gambar Interior dan Ekterior Bangunan Gedung dan Menggambar Dengan Perangkat Lunak) tidak berpengaruh terhadap kesiapan kerja siswa kelas XII Teknik Gambar Bangunan tetapi hasil nilai prestasi dapat mempengaruhi atau menjadi pertimbangan untuk siswa ketika setelah lulus akan melamar sebuah pekerjaan.

3. Pengaruh Praktik Kerja Industri (PRAKERIN) dan prestasi belajar mata pelajaran produktif terhadap kesiapan kerja

Berdasarkan hasil perhitungan uji $\mathrm{F}$ diperoleh nilai sign 0,000 ini menunjukkan bahwa nilai sign pada hasil SPSS $<0,05$, maka Ho ditolak dan $\mathrm{Ha}$ diterima sehinga terdapat pengaruh Praktik Kerja Industri (PRAKERIN) dan prestasi belajar mata pelajaran produktif terhadap kesiapan kerja. Praktik Kerja Industri (PRAKERIN) dan Prestasi Belajar secara bersama memberikan kontribusi terhadap kesiapan kerja sebesar 62,9\%. Pada hipotesis pertama variabel Praktik Kerja Industri (PRAKERIN) berpengaruh dalam kesiapan kerja, berbalik dengan hipotesis kedua variabel prestasi belajar mata pelajaran produktif tidak berpengaruh dengan kesiapan kerja, sedangkan pada hipotesis ketiga 


\begin{abstract}
variabel Praktik Kerja Industri (PRAKERIN) dan variabel prestasi belajar mata pelajaran produktif memiliki pengaruh terhadap kesiapan kerja. Hal ini menunjukkan bahwa prestasi belajar mata pelajaran produktif berpengaruh untuk kelancaran Praktik Kerja Industri, ilmu teori dan praktik yang ada di sekolah menjadi bekal awal para siswa untuk melaksanakan prakerin di kelas XI. Dengan adanya bekal ilmu dan pengalaman baru yang siswa dapatkan selama Praktik Kerja Indutri (Prakerin) ini membuat pengaruh besar terhadap kesiapan kerja siswa.
\end{abstract}

\section{SIMPULAN}

1. Terdapat pengaruh antara Praktik Kerja Industri (PRAKERIN) terhadap kesiapan kerja siswa,

2. Tidak terdapat pengaruh antara prestasi belajar mata pelajaran produktif terhadap kesiapan kerja

3. Terdapat pengaruh yang signifikansi antara Praktik Kerja Industri (PRAKERIN) dan prestasi belajar mata pelajaran produktif terhadap kesiapan kerja siswa.

\section{SARAN}

1. Kepada siswa Pada saat pelaksanaan Praktik Kerja Industri (PRAKERIN) diusahakan mencari lokasi Dunia Kerja/Dunia Industri yang sudah bersertifikat dan layak untuk dijadikan tempat Praktik Kerja Industri (PRAKERIN).

2. Kepada guru pembimbing Guru hendaknya selalu memantau atau berkomunikasi dengan siswanya tentang tugas dan lainya selama

\section{di Praktik Kerja Industri (PRAKERIN).}

3. Kepada kepala sekolah Pihak sekolah hendaknya memilihkan langsung tempat Praktik Kerja Industri (PRAKERIN). Karena tempat Praktik Kerja Industri (PRAKERIN) juga akan berpengaruh dengan jaringan kerja antara sekolah dengan pihak Dunia Kerja/ Dunia Industri.

4. Kepada pembimbing DU/DI Bersikap tegas kepada setiap siswa, agar siswa lebih menghargai waktu dan pekerjaan di tempat Praktik Kerja Industri (PRAKERIN).

5. Kepada peneliti selanjutnya Dalam pembuatan angket kuisioner hendaknya mencari indikator dalam bab 2 kajian pustaka dan Mencari variabelvariabel lain yang lebih mendukung tentang kesiapan kerja.

\section{DAFTAR PUSTAKA}

Hamalik, O. (2007). Proses Belajar Mengajar. Jakarta : Bumi Aksara

Nur Syailla, Aulia. (2017). Pengaruh Praktik Kerja Industri dan Motivasi Kerja Terhadap Kesiapan Kerja Siswa Kelas XII SMK Negeri 2 Tenggarong Tahun Ajaran 2016/2017. Jurnal PSIKOBORNEO, Volume 5, Nomor 3, 2017. Hlm. 465-476. Fakultas Ilmu Sosial dan Ilmu Politik Universitas Mulawarman.

Rauf, H. (2017). Praktik Kerja Lapangan Kurikulum 2013 Rev 2017. Diperoleh 9 Januari 2019, 
Dari:https://smknsatubanyuputih.wor dpress.com/2017/11/11/praktekkerja-lapangan-kurikulum-2013rev-2017/

Suryanti, Lilis (2017). Pengaruh Praktik Kerja Lapangan Dan Prestasi Belajar Terhadap Kesiapan Memasuki Dunia Kerja Pada Siswa Kelas XI Program Keahlian Teknik Gambar Bangunan SMK N 5 Surakarta Tahun Pelajaran 2016/2017. Skripsi. Universitas Sebelas Maret, Surakarta

Trianingsih, Anis. (2016). Pengaruh Praktik Kerja Industri dan Prestasi Belajar Terhadap Kesiapan Kerja Siswa Kelas XI Administrasi Perkantoran SMK Negeri 1 Sukoharjo Tahun Ajaran 2015/2016. Skripsi. Universitas Sebelas Maret, Surakarta.

Sri Arum Sari, Novita. (2016). Hubungan Antara Prestasi Mata Diklat Produktif dan Pengalaman Praktik Kerja Industri dengan Tingkat Kesiapan Kerja Siswa Program Keahlian Akutansi SMK Negeri 1 Banyudono Tahun 2016. Skripsi. Universitas Sebelas Maret, Surakarta

Candra Sari, Hawa. (2016). Hubungan Antara Tingkat Konsep Diri Dengan Kesiapan Menghadapi Dunia Kerja Pada Mahasiswa Tingkat Akhir Di Jurusan Administrasi Bisnis (D3) Politeknik Negeri Sriwijaya. Laporan Tugas Akhir. Politeknik Negeri Sriwijaya. 